\title{
Characterization of Shiga toxin-producing Escherichia coli isolated from cattle and their contacts
}

\author{
Shimaa EL Mahmoudy, Adel El-gohary, Amro Mohamed, Hazem Ramadan, Mayada Gwida* \\ Department of Hygiene and Zoonoses, Faculty of Veterinary Medicine, Mansoura University, Mansoura 35516, Egypt
}

\section{ARTICLE HISTORY}

Received: 13.01.2021

Revised: 31.01.2021

Accepted:03.02.2021

Address correspondence to Mayada Gwida; Tel. +201003783173, E-mail: Mayada_gwida@mans.edu.eg; ORCID: 0000-0001-6312-4703

\section{ABSTRACT}

\begin{abstract}
Objective: To estimate the occurrence of Shiga toxin-producing $E$. coli (STEC) in cattle reared on farms versus those belonged to smallholders as well as their contact keepers.

Design: Descriptive study.

Samples: The study comprised 260 samples consisting of $f$ ninety each of $(n=90)$ for each of cattle feces and milk samples that were originated either from smallholding cattle $(n=30)$ or from farm cattle $(n=60)$ alongside eighty stool specimens were collected from smallholders contacts $(n=50)$ and farm workers $(\mathrm{n}=30)$.

Procedures: All samples were examined using conventional bacteriological and molecular techniques. Results: The overall occurrence of $E$. coli in animal samples was 25/180 with a percentage of 13.9. In cattle feces, it was $14.4 \%$ (13/90), whereas it was $13.3 \%$ (12/90) in milk samples. In human stool samples, E. coli i isolates were also identified in smallholders' contacts $(14 \%, 7 / 50)$ and farm workers $(16.7 \%$, $5 / 30$ ). The most prevalent serotypes obtained from farm cattle and their keepers were (0157 and 055) and from smallholders' cattle and their contact were (0111, 0157, and O11). The PCR analysis showed that stx 2 was the most predominant genotypes followed by stx1. The recovered $E$. coli isolates showed high resistance to penicillin $\mathrm{G}(97.3 \%)$ and $81 \%$ (30/37) of the tested strains exhibited multidrug resistance.

Conclusion and clinical relevance: the presence of Shiga toxigenic and multiple drug-resistant strains of $E$. coli in the study area poses a high potential risk. Hence, strict hygienic measures should be followed to reduce the risk of STEC occurrence in smallholding cattle and those in commercial farms.
\end{abstract}

Keywords: Shiga toxin-producing E. coli, cattle, milk, virulence genes

\section{INTRODUCTION}

Escherichia coli (E. coli) is one of the main gastrointestinal inhabitants in most mammalian species, including humans and birds. Most E. coli are commensal, but small proportions are potentially harmful and cause diseases worldwide [1].Shiga toxins-producing E. coli (STEC) are a group of highly pathogenic strains known as enterohaemorrhagic $E$. coli (EHEC) or verotoxins-producing E. coli (VTEC) [2]. It is considered as one of the most emerging foodborne zoonotic bacteria causing wide range of various clinical symptoms including watery or bloody diarrhea, and potentially lifethreatening syndromes such as hemorrhagic colitis (HC), thrombotic thrombocytopenic purpura (TTP), hemolytic uremic syndrome (HUS) and acute renal failure [3]. Approximately $5 \%$ of STEC infection can develop HUS and the mortality can reach to $10 \%$ [4]. Although E. coli 0157 is the most serotype associated with food-borne outbreaks, other serotypes as 026, 055, 0103, 0111, 0128, 091 and 0145 which have been linked to cases and emerging outbreaks of HUS [5].

Cattle is considered as a natural reservoir for STEC and the pathogen can contaminate food products at any point along the production chain: during slaughtering, milking, storage or packaging [6]. Strains of STEC are characterize by production of different virulence genes including shiga toxin (stx1 and stx2) which inhibit the synthesis of host cell protein leading to cell death, beside the adherence factor, intimin, coded by eae gene which play a critical role in intestinal attachment [5]. An additional virulence factors that harbored by some strains of STEC is enterohaemorrhagic hemolysin which encoded by $h l y A$ gene and associated with extra intestinal lesions and seems to affect several cells including erythrocytes, renal cells, lymphocytes and causing severe human illness [7].

In Egypt, no restricted rules are outlined for the usage of antibiotics either for treatments of infected humans or interfacing animal diseases. The improper use of antibiotics can potentially cause the emergence of antimicrobial resistance foodborne zoonotic bacteria in animal-derived foods especially milk and meat that is usually associated with outbreaks globally [8]. The resistance of $E$. coli to wide ranges of antibacterial classes has been reported worldwide [1], although the occurrence of multidrug resistance among $E$. coli strains is still a matter of concern. Despite the significance of STEC as emerging zoonotic illness, little is still known regarding their occurrence in apparently healthy smallholders and farm cattle as well as their contact persons. 
The present study was, therefore, undertaken to evaluate the occurrence of STEC and their virulence associated genes as well as antimicrobial susceptibility in a linked study population and to correlate the isolated STEC strains from smallholder versus farm cattle and contact persons to estimate the potential zoonotic relatedness.

\section{MATERIALS AND METHODS}

\subsection{Samples collection and preparation}

The study comprised 260 samples consisting of cattle feces $(n=90)$ and milk samples $(n=90)$ that were originated either from smallholding cattle $(n=30)$ or from farm cattle $(n=60)$ alongside eighty stool specimens were collected from smallholder's contacts $(n=50)$ and farm workers $(n=30)$. The study was conducted during 2018/2019 in Mansoura city, Dakahlia Governorate, Egypt. All the samples were collected under aseptic condition in sterile plastic cups and were transferred into individual sterile bags to be transported as soon as possible in insulated coolers to Hygiene and Zoonoses laboratory, Faculty of Veterinary Medicine, Mansoura University for bacteriological processing. The study follows the principles and specific ethical guidelines presented by Mansoura University also verbal consent was obtained from all owners prior to samples collection.

\subsection{Isolation and Identification of $E$. coli}

The isolation and identification of $E$. coli strains were performed according to standard methods ISO 7251:2005 [9]. Briefly one gram from each of animal fecal sample, human stool specimen and one $\mathrm{mL}$ of milk samples was added to 9 $\mathrm{mL}$ sterile Tryptone Soya Broth (TSB) (Oxoid, CM 0192) and were incubated at 37ㅇ C for $18 \mathrm{hrs.,} \mathrm{th}$ en an aliquot of $100 \mu \mathrm{L}$ was plated on Sorbitol MacConkey su pplemented with Cefixime $(0.05 \mathrm{mg} / \mathrm{L})$ and potassium tellurite (2.5mg/L) (CT-SMAC) (Oxoid CM0069), then incubated at 37 ㅇ $\mathrm{C}$ for $24 \mathrm{hrs}$ and were examined for the presence of suspected colonies. The suspected colonies were purified in Tryptone Soya Agar media (Oxoid, CM 0981) and were identified using different biochemical testes according to ISO 7251:2005 [9].

\subsection{Serotyping}

All the identified $E$. coli strains were serotyped by slide agglutination test using rapid diagnostic E.coli monovalent and polyvalent antisera sets according to Kok and others [10] in Food Analysis Center, Faculty of Veterinary Medicine, Benha University, Egypt.

\subsection{DNA extraction}

Genomic bacterial DNA was prepared by heating as previously described by Mohammed, and other reserachers [5]. In brief five bacterial colonies of the same morphological shape were picked up and mixed with $100 \mu \mathrm{l}$ of sterilized distilled water, then exposed to heat lysis in dry heat block at 95으 for 15 minutes and centrifuged at $13000 \mathrm{rpm}$ for 10 minutes. The supernatants were transferred to clean tubes and kept at - 20 ㅇ to use as DNA template.

\subsection{Molecular Characterization of E. coli isolates}

PCR reaction was performed in an individual reaction using thermal cycler (Biometra, Ltd, Kent, UK) to detect different virulence genes as stx1, stx2, eaeA and hlyA. The oligonucleotides primer sequences and their corresponding amplicon sizes were illustrated in (Table 1). The PCR reactions were carried out in a total volume of $20 \mu$ l consisting of $10 \mu \mathrm{L}$ of readymade PCR master mix (Fermentis, Biotech, Co.); $1 \mu \mathrm{L}$ of each primer, $1 \mu \mathrm{L}$ of DNA template and completed to $20 \mu \mathrm{L}$ with DNA free water. The amplification conditions were performed as described previously by Paton and Paton [11] (Table 1). An aliquot of each amplified product was run on a $1.5 \%$ agarose gel by electrophoresis then visualized and photographed by ultraviolet trans-illuminator.

\section{7. $P C R$ reaction for $r f b E 0157$ and flic 7 genes}

Molecular confirmation of the presumptive E. coli 0157:H7 isolates were performed using PCR assay to detect rfbE 0157 and flic 7 genes. PCR reaction for both genes was carried out in a reaction mixture $(25 \mu \mathrm{L})$ with the master mix $(12.5 \mu \mathrm{L})$, forward $(1 \mu \mathrm{L})$ and reverse $(1 \mu \mathrm{L})$ primers and template DNA $(1 \mu \mathrm{L})$ and completed to $25 \mu \mathrm{L}$ with sterilized PCR water. The thermal cycling condition for amplification of $r f b E$ o157 was done according to Myataza and their colleagues [12]; while for flic 7 was like that done by Sallam and others [3]. The used amplification conditions were illustrated in (Table1). PCR products were run in $1.5 \%$ agarose gel for 40 minutes at $100 \mathrm{~V}$ then visualized and photographed by U.V light.

\subsection{Susceptibility Testing}

The susceptibility to kanamycin (30ug), ciprofloxacin (5ug), amikacin (30ug), penicillin G (10IU), erythromycin (15ug), cephalothin (30ug), nalidixic acid (30ug), gentamicin (10ug), cefotaxime (30ug), ampicillin (10ug), tetracycline (30ug), doxycycline (30ug), streptomycin (10ug) and sulphamethoxazol (25ug) was determined by the disk diffusion method as described in Clinical and Laboratory Standards Institute guidelines [13].

\section{RESULTS}

The overall occurrence of $E$. coli in animal samples was $25 / 180$ with the percentage of 13.9 , in cattle feces the recovery rate was $14.4 \%(13 / 90)$ of which $20 \%(6 / 30)$ and $11.7 \%(7 / 60)$ were recovered from cattle reared as smallholders and from those belonged to farm, respectively while in milk samples, the occurrence was $13.3 \%$ (12/90), including $16.7 \%(5 / 30)$ and $11.7 \%(7 / 60)$ was recognized as $E$. coli in smallholder and farm cattle milk, respectively. In human stool specimens, $14 \%$ (7/50) and (16.7\%) 5/30 was identified as $E$. coli in smallholders contacts and farm workers, respectively (Table 2 ).

Serotyping of $E$. coli strains from smallholders cattle demonstrated that $0119,026,0157,011,0111$ and 0113 were identified from cattle feces with the percentage of 12.5 for each; whereas 0128, 0157, 011, 055 and 0146 were characterized in $20 \%$, for each serotype in cattle milk. For the owners of smallholders, the following serotypes were identified: 084, 0111, 0146, 011, 0157, 055 and 0111 with 
a percentage of $14.3 \%$, for each (Table 3 ). For cattle reared in farm, the obtained results revealed that 0146, 0111, 055, $\mathrm{O} 11$ and 0157 were identified with the percentage of $14.3 \%$ for each serotype in animal feces; whereas in milk the serotype were as follow: 026, 091, 0121, 0157, 055, 0146 and $011314.3 \%$, for each. While in farm workers, the obtained strains were $0128,055,011,0157$ and 0128 with the percentage of $20 \%$, for each (Table 4). Molecular characterization of the identified $E$. coli strains from animals' sources demonstrated that all the examined virulence genes were detected among animals' samples with the percentage of $32 \%$. (8/25) whereas, $24 \%(6 / 25)$ for stx2, eaeA, hlyA and it was $3 / 25(12 \%)$ for stx 1 , eaeA and $h l y A$. In human samples the predominant genes were stx1, stx2, eaeA and hlyA with the percentage of $25 \%(3 / 12) / 16.7 \%(2 / 12)$ for each of (stx2, eaeA, hlyA / stx1, eaeA, hlyA and stx1, stx2, and eaeA). The recovered $E$. coli isolates showed high resistance to penicillin G $(97.3 \%)$ followed by cephalothin and ampicillin (83.8\%, per each), erythromycin (72.9\%), however; most of the tested $E$. coli isolates showed susceptibility to gentamicin (91.9\%), amikacin (89.2\%), ciprofloxacin (86.5\%), doxycycline, kanamycin (72.9\%, per each) and sulphamethoxazol (67.5\%), respectively whereas $81 \%(30 / 37)$ of the tested isolates exhibited multidrug resistance (Table 5).

Table 1. Oligonucleotide primers sequences used for amplification of virulence associated genes in STEC isolates.

\begin{tabular}{|c|c|c|c|c|}
\hline Primer & Oligonucleotide sequence $\left(5^{\prime} \rightarrow 3^{\prime}\right)$ & $\begin{array}{l}\text { Product size } \\
\text { (bp) }\end{array}$ & $\begin{array}{l}\text { PCR cycling ( } 35 \\
\text { cycles) conditions }\end{array}$ & References \\
\hline $\begin{array}{l}\text { Stx1 (F) } \\
\text { Stx1 (R) } \\
\text { Stx2(F) }\end{array}$ & $\begin{array}{l}\text { 5' ATAAATCGCCATTCGTTGACTAC '3 } \\
\text { 5' AGAACGCCCACTGAGATCATC '3 } \\
\text { 5' GGCACTGTCTGAAACTGCTCC' } \mathbf{3}\end{array}$ & $\begin{array}{l}180 \\
225\end{array}$ & & \\
\hline Stx2(R) & 5' TCGCCAGTTATCTGACATTCTG '3 & & & \\
\hline $\begin{array}{l}\text { eaeA }(\mathrm{F}) \\
\text { eaeA (R) }\end{array}$ & $\begin{array}{l}\text { 5' GACCCGGCACAAGCATAAGC '3 } \\
\text { 5' CCACCTGCAGCAACAAGAGG '3 }\end{array}$ & 384 & $\begin{array}{l}95^{\circ} \mathrm{C} \text { for } 5 \mathrm{~min} \\
58^{\circ} \mathrm{C} \text { for } 30 \mathrm{~s} \\
72^{\circ} \mathrm{C} \text { for } 30 \mathrm{~s}\end{array}$ & Paton and Paton (1998) \\
\hline $\begin{array}{l}\text { hlyA (F) } \\
\text { hlyA (R) }\end{array}$ & $\begin{array}{l}\text { 5'GCATCATCAAGCGTACGTTCC'3 } \\
\text { 5'AATGAGCCAAGCTGGTTAAGCT'3 }\end{array}$ & 530 & & \\
\hline $\begin{array}{l}r f b E_{0157}(\mathrm{~F}) \\
r f b E_{0157}(\mathrm{R})\end{array}$ & $\begin{array}{l}\text { 5' CTACAGGTGAAGGTGGAATGG'3 } \\
\text { 5' ATTCCTCTCTTTCCTCTGCGG'3 }\end{array}$ & 327 & $\begin{array}{l}94^{\circ} \mathrm{C} \text { for } 30 \mathrm{~s} \\
60^{\circ} \mathrm{C} \text { for } 90 \mathrm{~s}\end{array}$ & Myataza et al. (2017) \\
\hline $\begin{array}{l}f l i C 7(\mathrm{~F}) \\
f l i C 7(\mathrm{R})\end{array}$ & $\begin{array}{l}\text { 5'-CGGATGGCACAAGTCATTAATACC-3' } \\
\text { 5'-TTAACCCTGCAGCAGAGACAGAA-3' }\end{array}$ & 1758 & $\begin{array}{l}72^{\circ} \mathrm{C} \text { for } 90 \mathrm{~s} \\
98^{\circ} \mathrm{C} \text { for } 10 \mathrm{~s} \\
58^{\circ} \mathrm{C} \text { for } 30 \mathrm{~s} \\
68^{\circ} \mathrm{C} \text { for } 90 \mathrm{~s}\end{array}$ & Sallam et al. (2013) \\
\hline
\end{tabular}

Table 2. Frequency distribution of $E$. coli.

\begin{tabular}{|c|c|c|c|c|}
\hline & Samples & Examined & Positive & $\%$ \\
\hline \multirow[t]{3}{*}{ Cattle } & Smallholder feces & 30 & 6 & 20 \\
\hline & Farm feces & 60 & 7 & 11.7 \\
\hline & Total & 90 & 13 & 14.4 \\
\hline \multirow[t]{2}{*}{ Milk } & Smallholder milk & 30 & 5 & 16.7 \\
\hline & Farm milk & 60 & 7 & 11.7 \\
\hline \multirow{4}{*}{ Human } & Total & 90 & 12 & 13.3 \\
\hline & $\begin{array}{l}\text { Smallholder } \\
\text { contacts }\end{array}$ & 50 & 7 & 14 \\
\hline & Farm workers & 30 & 5 & 16.7 \\
\hline & Total & 80 & 12 & 15 \\
\hline Total & & 260 & 37 & 14.2 \\
\hline
\end{tabular}

\section{DISCUSSION}

Infection by STEC is becoming a potential health concern and is gained a special attention worldwide. In the present study, the occurrence of $E$. coli in cattle feces concurred with that given by Rehman and others [14], while being higher than those reported by $[15,16]$ and lower than those reported by others $[6,17]$. For milk samples, our findings were consistent with previous studies $[6,18]$ who identified E coli in $19 \%$ and $17 \%$ E. coli in $19 \%$ and $17 \%$ of the examined milk samples, respectively. In contrast, high isolation rates $(30,66.6$ and $38 \%)$ were reported by other researcher [ $19,20,17]$. The presence of $E$. coli in human samples were in agreement with that previously mentioned by Awadallah et al. [21] who identified E. coli in $20 \%$ from the examined samples; while high rates of occurrence were given by [19, 20]. Nevertheless, low rates of occurrence $(2.9,8.9,7 \%)$ were reported by other researchers $[\mathbf{7}, \mathbf{2 2}, \mathbf{2 3}]$. The difference in the isolation rate of $E$. coli in this study and other studies could be attributed to the differences in samples size, diversity of sampling and the methods used for isolation and characterization besides the lack of awareness, and poor personal hygiene.

In Egypt, nearly $70 \%$ of the livestock animals are reared by small farmers in which cattle are reared as domestic animal and account for $80-85 \%$ of the livestock population [24]. Our findings demonstrated that the most prevalent serotypes in smallholders and their contacts were 0111, 0157 and 011 (16.7\%; 3/18, per each) and these were like 
that previously reported by other researchers $[\mathbf{2}, \mathbf{6}, \mathbf{2 5}, \mathbf{2 6}]$. The PCR analysis showed that the most predominant genotypes were stx2 (15/18) 83.3\%, stx1 (13/18) $72 \%$ and eaeA genes (12/18) $66.7 \%$ and this agreed with that previously mentioned by several researchers $[6,27,28]$ while low detection rates were reported by other researchers, contacts.

\begin{tabular}{|c|c|c|c|c|c|}
\hline Isolate origin & Serotype & $\%$ of recovery & Positive genes & Resistance profile & $\begin{array}{l}\text { Multidrug } \\
\text { resistant } \\
\text { index }\end{array}$ \\
\hline \multirow{6}{*}{$\begin{array}{l}\text { Smallholder animal } \\
\text { feces } n=6\end{array}$} & 0119 & 16.7 & Stx1, stx2 & S, E, NA, P, CN, SXT, CF, T, AM & 0.643 \\
\hline & 026 & 16.7 & Stx1, stx2, eaeA, hlyA & $\begin{array}{l}\text { S, E, NA, P, CN, SXT, CF, T, AM, K, CP, AK, } \\
\text { DO }\end{array}$ & 0.928 \\
\hline & 0157 & 16.7 & Stx2, eaeA, hlyA & $E, P, C N, A M$ & 0.285 \\
\hline & 011 & 16.7 & Stx1, eaeA, hlyA & $\mathrm{P}, \mathrm{CN}, \mathrm{AM}, \mathrm{K}$ & 0.285 \\
\hline & 0111 & 16.7 & Stx1, stx2, eaeA, hlyA & $S, E, N A, P, C N, S X T, C F, T, A M, D O$ & 0.714 \\
\hline & 0113 & 16.7 & Stx1, stx2, eaeA, hlyA & $P, A M, K$ & 0.214 \\
\hline \multirow[t]{5}{*}{$\begin{array}{l}\text { Smallholder animal } \\
\text { milk } n=5\end{array}$} & 0128 & 20 & Stx1 & $\begin{array}{l}\text { S, E, NA, P, CN, SXT, CF, T, AM, K, CP, AK, } \\
\text { DO, G }\end{array}$ & 1 \\
\hline & O157 & 20 & Stx2, eaeA, hlyA & $E, P, C N, A M$ & 0.285 \\
\hline & 011 & 20 & Stx1, stx2, eaeA, hlyA & $\mathrm{P}, \mathrm{CN}, \mathrm{AM}, \mathrm{K}$ & 0.285 \\
\hline & 055 & 20 & Stx2, eaeA, hlyA & $S, E, P, C N, C F, T, A M, D O$ & 0.571 \\
\hline & 0146 & 20 & Stx1, stx2, hlyA & $P, C N, A M$ & 0.214 \\
\hline \multirow{7}{*}{$\begin{array}{l}\text { Smallholder } \\
\text { contacts } n=7\end{array}$} & 084 & 14.3 & Stx1 & $\mathrm{S}, \mathrm{E}$ & 0.143 \\
\hline & 0111 & 14.3 & Stx2, hlyA & S, E, NA, P, CN, SXT & 0.428 \\
\hline & 0146 & 14.3 & Stx1, stx2, eaeA & $\mathrm{P}, \mathrm{CN}, \mathrm{AM}$ & 0.214 \\
\hline & 011 & 14.3 & Stx1, stx2, eaeA & $\mathrm{P}, \mathrm{CN}, \mathrm{AM}, \mathrm{K}$ & 0.285 \\
\hline & 0157 & 14.3 & Stx1, stx2, eaeA, hlyA & $E, P, C N, A M, G$ & 0.357 \\
\hline & 055 & 14.3 & Stx1, stx2, eaeA, hlyA & $E, P, C N, T, A M, D O$ & 0.428 \\
\hline & 0111 & 14.3 & Stx1, stx2, hlyA & $S, E, N A, P$ & 0.285 \\
\hline
\end{tabular}

Our findings demonstrated that 0157 (26.3\%) and 055 $(15.8 \%)$ were the most prevalent serotypes obtained in farm cattle and their workers which were in harmony with that reported by different researchers $[17, \mathbf{1 8}, \mathbf{3 0}]$. On the other side, the main virulence genes determined in cattle reared in farm and their contacts were stx2 84.2\% (16/19), stx1 68.4\% $(13 / 19)$ and $84.2 \%(16 / 19)$ for eaeA gene which were in agreement with that reported in other studies $[6,7,31]$ they found that $s t \times 2$ was the predominant genotype in different examined sources while being disagreed with Abotalp and others [17] who found that stx1 was the predominant genotype in the examined cattle feces.

The identified serotypes in the study were categorized as EHEC (0157, 0111) which known to cause HC and HUS in human [32], EPEC (O55) which responsible for infantile diarrhea [33] and ETEC (011) was also identified and it was incriminated in severe cholera like syndrome [34]. Several previous researchers have reported that strains carrying stx 2 are potentially more virulent than those carrying stx 1 or even strains carrying both stx 1 and stx 2 are often implicated with
Kalender [29] who identified stx1 and stx2 with the percentages of 18,14 , respectively in the examined cattle rectal swabs. Also, Ramadan and others [2] detected stx1, stx2 and eaeA genes with the percentages of 27.8, 19.4 and 50 , respectively in stool samples. 
kanamycin (13.89\%) and gentamicin (2.7\%) [26]. Collectively, the high resistance of $E$. coli strains to the tested antimicrobials could be attributed to the excessive and uncontrolled usage of these antimicrobial agents in the treatment of various clinical entities under field condition.

The present study has its own limitation including unequal sample size collected from smallholder cattle and those raised in the commercial farm. Further studies are also needed to elucidate the potential ability of different STEC serotypes to form biofilm.

\section{Conclusion}

The presence of shiga toxigenic and multiple drug resistant strains of $E$. coli in the study area poses a high potential risk especially in the absence of strict hygienic practices and preventive measures. Hence, strict hygienic measures should be followed to reduce the risk of STEC occurrence in smallholding cattle and those in commercial farms and to avoid the dissemination of such pathogenic $E$. coli strains in food production chains
Table 5. Antimicrobial susceptibility of $E$. coli strains $(n=37)$ isolated from different sources.

\begin{tabular}{lllll} 
& & & & \\
Antimicrobial agent & S & & R & \\
Streptomycin (S) & No & $\%$ & No & $\%$ \\
Erythromycin (E) & 20 & 54 & 17 & 45.9 \\
Nalidixic acid (NA) & 10 & 27 & 27 & 72.9 \\
Penicillin G (P) & 23 & 62 & 14 & 37.8 \\
Cephalothin (CN) & 1 & 2.7 & 36 & 97.3 \\
Sulphamethoxazol (SXT) & 6 & 16.2 & 31 & 83.8 \\
Cefotaxim (CF) & 25 & 67.5 & 12 & 32.4 \\
Tetracycline (T) & 23 & 62 & 14 & 37.8 \\
Ampicillin (AM) & 23 & 62 & 14 & 37.8 \\
Kanamycin (K) & 6 & 16.2 & 31 & 83.3 \\
Ciprofloxacin (CP) & 27 & 72.9 & 10 & 27 \\
Amikacin (AK) & 32 & 86.5 & 5 & 13.5 \\
Doxycycline (DO) & 33 & 89.2 & 4 & 10.8 \\
Gentamicin (G) & 27 & 72.9 & 10 & 27 \\
\hline & 34 & 91.9 & 3 & 8 \\
\hline
\end{tabular}

Table 4. Antibiograms, serotypes and molecular characterization of E. coli strains isolated from farm cattle and their workers.

\begin{tabular}{|c|c|c|c|c|c|}
\hline Isolate origin & Serotype & $\%$ of recovery & Positive genes & Resistance profile & $\begin{array}{l}\text { Multidrug } \\
\text { resistant index }\end{array}$ \\
\hline \multirow[t]{7}{*}{ Feces $n=7$} & 0157 & 14.3 & Stx1, stx2, eaeA, hlyA & $S, E, N A, P, C N, S X T, C F, T$ & 0.571 \\
\hline & 0146 & 14.3 & Stx2 & $S, E, N A, P, C N, S X T, C F$ & 0.500 \\
\hline & 0111 & 14.3 & Stx1, stx2, eaeA, hlyA & $\mathrm{S}, \mathrm{E}, \mathrm{NA}, \mathrm{P}, \mathrm{CN}, \mathrm{SXT}, \mathrm{CF}, \mathrm{T}, \mathrm{AM}, \mathrm{K}, \mathrm{CP}, \mathrm{AK}, \mathrm{DO}, \mathrm{G}$ & 1 \\
\hline & 055 & 14.3 & Stx2, eaeA, hlyA & $S, E, P, C N, C F, T, A M, D O$ & 0.571 \\
\hline & 011 & 14.3 & Stx2, eaeA, hlyA & $P, C N, A M, K$ & 0.285 \\
\hline & 0157 & 14.3 & Stx1, stx2, eaeA & $\mathrm{E}, \mathrm{P}, \mathrm{CN}, \mathrm{AM}$ & 0.285 \\
\hline & 0157 & 14.3 & Stx1, stx2, eaeA, hlyA & $\mathrm{E}, \mathrm{P}, \mathrm{CN}, \mathrm{AM}$ & 0.285 \\
\hline \multirow[t]{7}{*}{ Milk n= 7} & 026 & 14.3 & Stx1, stx2, eaeA, hlyA & $S, E, N A, P, C N, S X T, C F, T, A M$ & 0.643 \\
\hline & 091 & 14.3 & Stx1, stx2 hlyA & $S, E, N A, P, C N, S X T, C F, T, A M, K, C P$ & 0.786 \\
\hline & 0121 & 14.3 & Stx1, stx2 & $S, E, N A, P$ & 0.285 \\
\hline & 0157 & 14.3 & $\begin{array}{l}\text { Stx1, eaeA, hlyA, } \\
r f b E_{0157}\end{array}$ & $\mathrm{E}, \mathrm{P}, \mathrm{CN}, \mathrm{AM}$ & 0.285 \\
\hline & 055 & 14.3 & Stx1, stx2, eaeA & $S, E, P, C N, C F, T, A M, D O$ & 0.571 \\
\hline & 0146 & 14.3 & Stx1, stx2, eaeA & $\mathrm{P}, \mathrm{CN}, \mathrm{AM}$ & 0.214 \\
\hline & 0113 & 14.3 & Stx2, eaeA, hlyA & $\mathrm{P}, \mathrm{AM}, \mathrm{K}$ & 0.214 \\
\hline \multirow[t]{5}{*}{ Worker $n=5$} & 0128 & 20 & Stx2, eaeA, hlyA & $S, E, N A, P, C N, S X T, C F, T, A M, D O$ & 0.714 \\
\hline & 055 & 20 & Stx1, stx2, eaeA, hlyA & $E, P, C N, A M$ & 0.285 \\
\hline & 011 & 20 & Stx1, eaeA, hlyA & $P, A M, K$ & 0.214 \\
\hline & 0157 & 20 & Stx1, eaeA, hlyA, flic 7 & $\mathrm{E}, \mathrm{P}, \mathrm{CN}, \mathrm{AM}$ & 0.285 \\
\hline & 0128 & 20 & Stx2, eaeA, hlyA & $E, P, C F, A M S, E, N A, P, C N, S X T, C P, T, A K, D O$ & 0.714 \\
\hline
\end{tabular}

\section{Conflict of interest}

There is no conflict of interest.

Author contributions:
Shimaa El-Mahmoudy performed the lab work and wrote the first draft, Mayada Giwda designed the study, management and coordination responsibility for the research activity planning and execution, reviewing and editing the 
article. Adel El-Gohary and Amro Mohamed revised the final version. All authors have read and approved the final version of the manuscript for publication.

\section{REFERENCES}

[1] Hamed OM, Sabry MA, Hassanain NA, Hamza E, Hegazi AG, Salman MB. Occurrence of virulent and antibiotic-resistant Shiga toxin-producing Escherichia coli in some food products and human stool in Egypt. Vet World. 2017;10:1233. https://doi.org/10.14202/vetworld.2017.1233-1240

[2] Ramadan H, Awad A, Ateya A. Detection of phenotypes, virulence genes and phylotypes of avian pathogenic and human diarrheagenic Escherichia coli in Egypt. J Infect Dev Countr 2016;10:584-91. https://doi.org/10.3855/jidc.7762

[3] Sallam KI, Mohammed MA, Ahdy AM, Tamura T. Prevalence, genetic characterization and virulence genes of sorbitol-fermenting Escherichia coli O157: H-and E. coli O157: H7 isolated from retail beef. Int. J Food Microbiol 2013;165:295-301. https://doi.org/10.1016/j.ijfoodmicro.2013.05.024

[4] Rhoades J, Duffy G, Koutsoumanis K. Prevalence and concentration of verocytotoxigenic Escherichia coli, Salmonella enterica and Listeria monocytogenes in the beef production chain: a review. Int. J Food Microbiol 2009;26:357-76. https://doi.org/10.1016/j.fm.2008.10.012

[5] Mohammed MA, Sallam KI, Eldaly EAZ, Ahdy AM, Tamura T. Occurrence, serotypes and virulence genes of non-0157 Shiga toxin-producing Escherichia coli in fresh beef, ground beef, and beef burger. Food control 2014;37:182-7. https://doi.org/10.1016/j.foodcont.2013.09.035

[6] Merwad A, Gharieb R, Saber T. Occurrence of shiga toxin-producing Escherichia coli in lactating cows and in contact workers in Egypt: serotypes, virulence genes and zoonotic significance. Life Sci J. 2014;11:563-71.

[7] Ahmed H, MacLeod ET, El Bayomi RM, Mohsen RA, Nassar AH. Molecular Characterization of Escherichia coli O157: H7 and non-O157 Shiga Toxin Producing E. coli from Retail Meat and Humans. Zag Vet J 2017;45:25061. https://doi.org/10.21608/zvjz.2017.7950

[8] Abd-Elghany S, Sallam K, Abd-Elkhalek A, Tamura T. Occurrence, genetic characterization and antimicrobial resistance of Salmonella isolated from chicken meat and giblets. Epidemiol Infect 2015;143:997-1003. https://doi.org/10.1017/S0950268814001708

[9] ISO I. 7251: 2005. Microbiology of food and animal feeding stuffshorizontal method for the detection and enumeration of presumptive Escherichia coli-most probable number technique. International Organization for Standardization. 2005.

[10] Kok T, Worswich D, Gowans E. Some serological techniques for microbial and viral infections. Practical Medical Microbiology (Collee, J; Fraser, A; Marmion, B and Simmons, A, eds), 14th ed, Edinburgh, Churchill Livingstone, UK. 1996:179-204.

[11] Paton JC, Paton AW. Pathogenesis and diagnosis of Shiga toxinproducing Escherichia coli infections. J Clin Microbiol reviews 1998;11:450-79. https://doi.org/10.1128/CMR.11.3.450

[12] Myataza A, Etinosa O, Ehimario U, Nolonwabo N, Anthony I. Incidence and antimicrobial susceptibility of Escherichia coli O157: H7 isolates recovered from dairy farms in Amathole District Municipality, Eastern Cape, South Africa. Asian Pac J Trop Dis 2017;7:765-70. https://doi.org/10.12980/apjtd.7.2017D7-198

[13] Clinical, Institute LS. Performance standards for antimicrobial susceptibility testing. Clinical and Laboratory Standards Institute Wayne, PA; 2017.

[14] Rehman MU, Rashid M, Ahmad Sheikh J, Ahmad Wani S, Farooq S. Multidrug resistance among Shiga toxin producing Escherichia coli isolated from bovines and their handlers in Jammu region, India. Vet World. 2013;6. https://doi.org/10.14202/vetworld.2013.655-658

[15] EL-Alfy SM, Ahmed SF, Selim SA, Aziz MHA, Zakaria AM, Klena JD. Prevalence and characterization of Shiga toxin 0157 and non-0157 enterohemorrhagic Escherichia coli isolated from different sources in Ismailia, Egypt. Afr J Microbiol Res 2013;7:2637-45. https://doi.org/10.5897/AJMR2013.5417

[16] Galal H, Hakim A, Dorgham S. Phenotypic and virulence genes screening of Escherichia coli strains isolated from different sources in delta Egypt. J. Life Sci. 2013;10:352-61.
[17] Abotalp EH, Abdeen E, Moustafa AE-DH, Mohamed SR. Molecular Detection of Virulence Genes of Escherichia Coli 0157 Isolated from Different Sources. Alex J Vet Sci 2017;53. https://doi.org/10.5455/ajvs.262860

[18] Ahmed AS, Diab HM, Alkahtani MA, Alshehri MA, Saber H, Badr H, et al. Molecular epidemiology of virulent $E$. coli among rural small scale dairy herds and shops: Efficacy of selected marine algal extracts and disinfectants. Int J Environ Health Res 2020:1-23. https://doi.org/10.1080/09603123.2020.1727422

[19] Gwida M, El-Gohary F. Zoonotic bacterial pathogens isolated from raw milk with special reference to Escherichia coli and Staphylococcus aureus in Dakahlia Governorate, Egypt. Governorate, Egypt. 2013;2:705.

[20] Selim S, Ahmed S, Aziz MA, Alfay S, Zakaria A, Klena J, et al. Comparative pathogenicity, toxicity and pulse types of 0157 and non-0157 Escherichia coli. Minerva Biotecnologica 2014;26:7-16.

[21] Awadallah MA, Ahmed HA, Merwad AM. Prevalence of non-0157 shiga toxin-producing Escherichia coli and Enterotoxigenic staphylococci in ready-to-eat meat products, handlers and consumers in Cairo, Egypt. Glob Vet 2014;12:692-9.

[22] Sharaf EF, Shabana II. Prevalence and molecular characterization of Shiga toxin-producing Escherichia coli isolates from human and sheep in Al-Madinah Al-Munawarah. J Infect 2017;21:81-7. https://doi.org/10.22354/in.v21i2.651

[23] Shaaban SI, Ayoub MA, Ghorbal SH, Nossair M. Calves as a Reservoir of Some Diarrheagenic Agents for Human Contacts in El-Behira Province. Alex J Vet Sci 2018;56. https://doi.org/10.5455/ajvs.285867

[24] Aidaros H. Global perspectives-the Middle East: Egypt. Revue Scientifique Et Technique-Office Rev Sci Tech Oie 2005;24:589. https://doi.org/10.20506/rst.24.2.1592

[25] Alexa P, Konstantinova L, Sramkova-Zajacova Z. Faecal shedding of verotoxigenic Escherichia coli in cattle in the Czech Republic. Vet MedCzech 2011;56:149-55. https://doi.org/10.17221/3152-VETMED

[26] Elafify M, Khalifa HO, Al-Ashmawy M, Elsherbini M, El Latif AA, Okanda $T$, et al. Prevalence and antimicrobial resistance of Shiga toxin-producing Escherichia coli in milk and dairy products in Egypt. J Environ Sci Health C, 2020;55:265-72. https://doi.org/10.1080/03601234.2019.1686312

[27] Fernández D, Irino K, Sanz M, Padola N, Parma A. Characterization of Shiga toxin-producing Escherichia coli isolated from dairy cows in Argentina. Lett Appl Microbiol 2010;51:377-82. https://doi.org/10.1111/j.1472-765X.2010.02904.x

[28] Sethulekshmi C, Latha C, Anu C. Occurrence and quantification of Shiga toxin-producing Escherichia coli from food matrices. Vet World 2018;11:104. https://doi.org/10.14202/vetworld.2018.104-111

[29] Kalender H. Isolation, virulence genes and antimicrobial susceptibilities of Shiga Toxin-Producing Escherichia coli 0157 from slaughtered cattle in abattoirs and ground beef sold in Elazığ. Kafkas Univ Vet Fak Dergi. 2013;19.

[30] Oporto B, Ocejo M, Alkorta M, Marimón J, Montes M, Hurtado A. Zoonotic approach to Shiga toxin-producing Escherichia coli: integrated analysis of virulence and antimicrobial resistance in ruminants and humans. $\quad$ Epidemiol Infect 2019;147. https://doi.org/10.1017/S0950268819000566

[31] Sheikh JA, Rashid M, Rehman MU, Bhat M. Occurrence of multidrug resistance shiga-toxin producing Escherichia coli from milk and milk products. Vet World 2013;6:915. https://doi.org/10.14202/vetworld.2013.915-918

[32] Cordonnier C, Etienne-Mesmin L, Thévenot J, Rougeron A, Rénier S, Chassaing B, et al. Enterohemorrhagic Escherichia coli pathogenesis: role of Long polar fimbriae in Peyer's patches interactions. Sci Rep 2017;7:44655. https://doi.org/10.1038/srep44655

[33] Maity T, Kumar R, Misra A. Prevalence of enteropathogenic Escherichia coli isolated from chhana based Indian sweets in relation to public health. Indian J Microbiol 2010;50:463-7. https://doi.org/10.1007/s12088-011-0102-9

[34] Qadri F, Svennerholm A-M, Faruque A, Sack RB. Enterotoxigenic Escherichia coli in developing countries: epidemiology, microbiology, clinical features, treatment, and prevention. Clin Microbiol Rev 2005;18:465-83. https://doi.org/10.1128/CMR.18.3.465-483.2005

[35] Brooks JT, Sowers EG, Wells JG, Greene KD, Griffin PM, Hoekstra RM, et al. Non-0157 Shiga toxin-producing Escherichia coli infections in the United States, 1983-2002. J Infect.Dis 2005;192:1422-9. https://doi.org/10.1086/466536 
[36] Pradel N, Bertin Y, Martin C, Livrelli V. Molecular analysis of shiga toxinproducing Escherichia coli strains isolated from hemolytic-uremic syndrome patients and dairy samples in France. Appl Environ Microbiol 2008;74:2118-28. https://doi.org/10.1128/AEM.02688-07

[37] Blanco M, Blanco J, Mora A, Dahbi G, Alonso M, González E, et al. Serotypes, virulence genes, and intimin types of Shiga toxin (verotoxin)- producing Escherichia coli isolates from cattle in Spain and identification of a new intimin variant gene (eae- $\xi)$. J Clin Microbiol 2004;42:645-51. https://doi.org/10.1128/AEM.02688-07 